\title{
Agata Bachórz*
}

University of Gdańsk

\section{HIDDEN RESOURCES? HOUSEHOLDS' STRATEGIES FOR MAINTAINING CONTROL OVER FOOD: BETWEEN CONTINUITY AND DISCONTINUITY}

\begin{abstract}
This paper deals with internal household strategies for regaining control over quality, safety and the meaning of food, as applied by people in Poland. Using material gathered by interviewing representatives of two generations, the paper analyses the bottom-up, scattered and intra-family solutions woven into the structure of everyday life. Although alternative food networks and food activism are emerging nowadays as an important area of criticism towards contemporary food production and supply, the paper goes back to the choices made within the mainstream food system. Although the interviewees could be classified as middle-class and for this reason are expected to eagerly adapt to new lifestyle patterns, the research material allows one to focus not only on the novelty in people's culinary choices, but above all - on the continuity. Forms of domestic cooking and buying provisions for the household - as embodied skills based on physical work and time available - are interpreted in the light of contemporary food distrust. The similarities between late modern and traditional mechanisms of maintaining trust are analysed, showing how different layers overlap, shaping a mix of traditional and modern forms.
\end{abstract}

Keywords: food trust, domestic cooking, household economy, intergenerational transmission, tradition, modernity, post-socialism

\section{INTRODUCTION AND THE RESEARCH QUESTIONS}

The aim of the paper is to focus on internal household strategies for food supply and food preparation in contemporary Poland in the face of global gastronomic anxiety. The changing modes of food production, transportation and trade in late modern societies and their consequences such as lack of transparency, manipulation of food ingredients, and impact on the environment, cause concern, exacerbated by periodically disclosed food scandals. These transformations reciprocally react with the new forms of reflexivity of social actors, which creates a deficit of consumer trust as a central, although not homogeneous in the spatial or historical sense, problem of contemporary foodscapes (Kjaernes, Harvey and Warde 2007).

* Corresponding author: Agata Bachórz, Uniwersytet Gdański, Wydział Nauk Społecznych, ul. Jana Bażyńskiego 4, 80-309 Gdańsk; e-mail: agata.bachorz@ug.edu.pl. 
In the face of this uncertainty, social actors not only permanently question our food systems but also seek out various strategies which should lead - in their opinion - to at least regaining partial control over the quality, safety and meaning of the consumed food. While different forms of food trust and distrust have been institutionalised and inscribed in social relationships (Kjaernes, Harvey, and Warde 2007: 8), people's choices are navigated not only by growing individualisation, but also by local traditions, which have not ceased to be a resource. Although reactions in the face of food anxieties can take the form of organised consumer behaviour based on the organic food sector, certification systems, alternative consumer networks, and intentional civil activism (DuPuis and Gillon 2009), these institutionalised solutions are not widespread in Poland, similarly to other post-socialist societies (cf. Jehlička and Smith 2011). It seems that the domination of both supermarket chains and very traditional ways of purchasing food make food alternatives rather a niche option (Bilewicz and Śpiewak 2015). Therefore, this paper describes the bottom-up solutions woven into the structure of everyday lives of Polish families and introduced through consumer choices made within the mainstream food provisioning system, supported by family resourcefulness and embodied knowledge. The paper seeks to explore these scattered, transparent intra-family and intergenerational strategies of maintaining the meaning of contemporary food.

In the light of global dietary anxiety, the main focus of academic interest in food has been placed on the breakdown of rules and ways of acting, stressing "gastro-anomy" (Fischler 1988: 288-290) rather than stability. Yet the diagnosis of radical transformation in people's eating habits, being a mirror of global, cultural and economic changes, conveys the stability and reproduction of nutritional behaviours which have not disappeared from people's everyday experience (Bugge and Almås 2006: 206). In the case of Poland - similarly to other societies from the former Soviet Bloc - global phenomena intersect with local specificity and historical legacy resulting in hybrid, heterogeneous forms framed by the category of post-socialism. The latter not only underlines radical change, discrepancies and the experience of uprooting, but also suggests focusing on "neglected" continuity (Dunn 2004; Stenning 2005; Smith and Jehlička 2007). Thus the paper analyses attempts to restore the desired properties of food using references to the past - both intentional and unintentional - as a resource. Even though people of different generations may declare their helplessness in the face of 'industrial contamination', the lack of transparency in food production and deceptive strategies of manufacturers and retailers, they try to some extent to minimalize those phenomena perceived as negative by referring to or reinterpreting well-established ways of eating within the family. They also use the past in less obvious ways when imitating new, global, coping strategies which turn out to overlap traditional ones.

The empirical data used in the paper come from research conducted in 2015, based on in-depth interviews with representatives of two generations of Poles. A total of 22 people participated in the study. Adult children (mostly daughters) and their parents (mostly mothers) were interviewed about their daily habits referring to eating and meal preparation, meanings associated with domestic cooking, the sources of the culinary knowledge they use, and changes in practices and opinions about food during their lifetime. The interviews were not dyadic: they were conducted separately with each person and covered the issues of individual households. However, inevitably, mutual references have appeared in the accounts of children 
Hidden resources? Households' strategies for maintaining control over food...

and parents. Inviting two generations to participate in the research served not only to give an insight into the opinions of people of very different ages ranging from 18 to over 80, but also to gain an opportunity to trace intergenerational transmissions or breakdowns as well as the collective dimension of performed behaviour.

The study was conducted amongst people living in a large Polish city (however some of the parents have rural backgrounds, having migrated from the countryside in the early stages of their lives). The participants were educated (all the children and the majority of the parents with higher education), and with no particular economic problems (all the interviewees evaluated their economic status as average, good or very good). The group of interviewees, thus, could be defined as representatives of the middle class, although one should bear in mind the specificity of the Polish middle class, as it evolves, with blurred boundaries and relatively unsecure financial status in comparison to European standards.

The constraints of the sample are clearly visible here, although the selection of interviewees turned out to be highly useful from the perspective of the paper's questions. Urban, relatively well-situated and educated, they should be the most disposed to assimilate global lifestyle patterns, also having the cultural and economic capital to do so. Their lifestyle aspirations could be perceived as rather Western-oriented, with imitation as an important identity-building mechanism (Horolets 2013: 83-123). They are also expected to be reflexive in terms of incorporating discourses of individual obligations towards the body and health. At the same time, the interviewees turned out not to distance themselves from their parents either in the geographical or symbolic sense, not only living in the same city but also keeping strong ties with their relatives and adhering to similar values. Thus the study allows us to focus on the unobvious relationship between novelty and tradition, as they power each other.

In the first part of the paper, common ways of controlling food in households are described, mainly in the areas of domestic cooking and household provisioning. Everyday habits, although not spectacular and performed on a micro-level within the mainstream food system, may be interpreted as self-defence against undesirable phenomena. In the second part of the analysis, the paradoxical overlapping of two historical layers is emphasised. The paper explores how continuities and discontinuities, not without contradictions, intermingle in people's experiences. Past habits, reproduced through the generations and new lifestyle choices that have emerged after the Polish systemic transition, and global tendencies in the food system meet in households, shaping a mix of traditional and modern forms.

\section{DOMESTIC COOKING, THE ART OF SHOPPING, AND EMBODIED AGENCY}

The idea of "home-made food" could only have acquired meaning in modern times (cf. Goody 2013), as a consequence of the emergence of market and state food producers. Domestic meals, with the various values assigned to them - both positive and negative - have become a response or alternative for food production and consumption outside of households. In some modern contexts, "home-made" represents a family identity marker (Moiso, Arnould and Price 2004), while in others it is perceived as a normative ideal, sometimes becoming a symptom 
of backwardness and gender inequality (Short 2006). Along with the late-modern anxiety surrounding the food industry, domestic food preparation has gained a new "anti-industrial" meaning and become a highly valued, although threatened, craft practised reflexively by some.

In socialist Poland, similarly to other societies of Eastern Bloc, home-made food bore specific meanings. It was a part of general division between private and public spheres, where "public" was perceived by citizens as an inefficient, alien and threatening state, while the (extended) family became an area of both safety and bottom-up resourcefulness (Dunn 2004; Wedel 2007: 57-68). The private sphere served as an informal defence against unfriendly or poorly functioning public entities. It enabled escape from the centralised state economy, which tried to control the private lives of citizens but did so insufficiently. The incomplete nature of socialist modernisation relied, among others, on incorporating some elements of traditional culture which could serve as a source of coping strategies.

In particular, food shortages and economic difficulties caused the development of informal, non-market, semi-legal ways of acquiring food (Wedel 2007: 69-100; Mazurek 2010: 33-70; Kochanowski 2015), having, in turn, their roots in peasant culture and extant family relationships between urban and rural populations. Besides this, different forms of self-provisioning co-existed with the centrally planned economy, such as the self-sufficient cultivation of fruit and vegetables practised by members of different social classes, thanks to their urban garden allotments (Bellows 2004). In addition, domestic food production from scratch, combined with the sharing of it inside families, served as an area of individual agency, authenticity and a primal way of manifesting ones femininity and motherhood (Dunn 2004). Against this background, as Elizabeth Dunn claims, the home became an area of civic society, while domestic food preparation, although not political in the narrow sense, could be perceived as a kind of political engagement (Dunn 2004).

During the early stages of Polish post-socialist transformation the social costs of deep economic change were moderated more by individual, bottom-up productivity and thriftiness than by systemic solutions (Palska 2002; Rakowski 2009). This also concerned the area of food production. In general, non-market forms of producing and distributing food became an important component of post-Soviet and Eastern European economies (Smith and Stenning 2006). According to Alber and Kohler (2008), who analysed data from 2003, informal food production in post-socialist states should be perceived as a necessary coping strategy rather than recreational activity. At the same time, as regarding safety understood in both an economic and psychological sense, it should not be reduced to the temporary down-shifting strategy. Its significance is not only economical, but it is also linked to social ties and identities (cf. Ries 2009; Jehlička and Smith 2011). As Joanna Mroczkowska (2014: 76-85) has already presented with regard to home cooking in Poland, the importance of domestic food production can generally be interpreted as a response to the uncertainty of social transformations and supra-local processes which people are subject to with no individual influence.

Economic and political transformations have strongly influenced food production and the food market in Poland, to a certain degree changing the eating habits of Poles. They have shifted from food shortages towards obesity conditions (Kopczyńska and Zielińska 2015). It seems, however, that the change, to a limited extent, applies to eating out patterns, which remain rather traditional (Domański et al. 2015). Although large cities may be witnessing the 
growing phenomena of "foodie culture" (Derek 2017), existing knowledge of contemporary food habits allows one to argue that domestic cooking is an unchallenged part of Polish food culture. Quantitative research confirms that the majority of people prepare and eat meals at home (Domański et al. 2015: 122-125), although the middle-class is more prone to dine in restaurants (Domański et al. 2015: 131).

A general overview of Polish foodscapes does not stand in contradiction with the smaller scale qualitative research, however, which provides additional insight into the meanings of home-made: both old and new. For example, research on cultural participation indeed shows signs of shifting food preparation from work and home economics towards leisure, creativity or design, framed by the ideas of modern presumption (Bachórz et al. 2014: 60-62; cf. Short 2006: 5, 19-22). However, against this background, stable home cooking does not seem to be threatened, and the households I observed have not experienced "freedom from cooking" (Short 2006: 2), despite their relatively high financial status, which could allow them to spend the surplus on eating out. Home cooking is still declaratively perceived as an ideal - in the sample there was nobody who would definitely refuse the pattern.

Contradictory interpretations of this stability emerge from the accounts gathered: people running the households explain daily cooking either by its neutral commonness or by the emotional strength attached to it. On the one hand, the interviewed people do not cease to treat daily cooking as a transparent, obvious and automatic activity: as something one has to do without question. For example, a 30-year-old working woman estimates that she spends about three hours per day on shopping, organising, and preparing meals for herself and her husband. Although cooking is not her favourite pastime and she considers it to be "mechanical", at the same time she thinks it may be helpful for her husband, whose professional life, she assumes, is more engaging than hers. On the other hand, cooking and eating at home are perceived by some interviewees as filled with meaning mostly because they are inscribed into social relationships and identified with taking care. Another woman who took part in the research straight-away stated that she puts love into her home-cooked meals. She expresses the opinion that domestic food preparation is the exact opposite of meals purchased in bars and restaurants, which, even though they may be a nice departure from the routine, are devoid of all these emotional connotations.

In general, the participants in the study do not value dining out on a daily basis, usually do not value ready-made products, and do not try to replace cooking at home. Relatively little space is left for exceptions: they may be linked to special occasions, or - on the contrary - the coercion of the daily rush (cf. Warde and Martens 2003: 47). The traditionally high position of domestic cooking seems particularly interesting from a food safety perspective. It is clearly visible that there are a few who cook at home on a daily basis and admit to not liking it. The "objective" necessity and traditionally driven obligations towards loved ones are just a partial explanation. The interviewees find themselves under the pressure of their own beliefs about "the proper meal", which lately means not only the proper processing and combining of ingredients (Murcott 1982), but may also be understood as devoid of unnecessary additives. In other words: contemporary food distrust adds another layer to that traditional and deeply embodied practice - domestic cooking allows one to control the process of food preparation by making it more transparent. For example, a 37-year-old woman who cooks almost every 
day for herself and her boyfriend declares her attachment to meals prepared at home even though, as she admits, it is time-consuming and seemingly could be replaced by eating out. She understands it as an obligation with two origins: both of them are expressed in the quotation below. Both family tradition and late modern reflexivity influence the interviewee's attitude:

Really I learnt it from my family that, you know, a meal at home is the best. You should eat that way, shouldn't you? Besides, eating out is really getting worse nowadays, no matter which restaurant you choose - it is just all going the easy way and it is not good quality food.

This attitude is not exceptional. The woman quoted above to some extent appreciates eating out and she still enjoys it from time to time. However, she also declares: We used to dine out a lot, but now we eat at home. Above all I know what I am eating, what I bought for myself. Preparing meals at home makes it possible to avoid at least some of the unclear moments of food production.

The statement about the unthreatened position of home-made food as well as its role in searching for the meaning of meals, is supported by the particular attitude towards the methods of food preparation based on recipes rooted within families, which still serve as a highly valued reference point. For instance, the interviewees inform that members of their parents' generation tend to change the stable repertoires of dishes they have been cooking for years, while the younger generations do not always appreciate these attempts. On the contrary: in some cases adult children criticise their parents' (mothers') tendency to be innovative, not sticking enough to well-known dishes or ineptly applying new additives and techniques. Interestingly, although a "proper meal" is one which should be transparent and consist of well-known ingredients, at the same time health regimes seem to be of lesser importance than taste and memory.

Conviction about the particular role of home-made food in contemporary everyday life is complemented by the widespread phenomenon of circulating food containers between households: home-made meals, prepared by the older generations in large quantities, are given to the adult children to take away. In spite of the possible embarrassment on the side of the younger generation, the research participants commonly confirm using this kind of support from their parents. Sharing home-made meals within the extended family brings to mind traditional patterns, even though it is taking place in contemporary urban circumstances. Transfer of food should obviously be understood as a part of a reciprocal system of love and care exchange, more than as material support. It enables the rootedness and stability of relations along with mutual obligations, as food is personalised, and assigned with meaning. This does not stand in contradiction with serving as a pragmatic tool for rebuilding control over food and keeping it inside the family in the face of the difficulties the younger generation has with traditional cooking.

The situation of a woman in her thirties who recently became a mother is a good example. She confesses to feeling guilty for not cooking from scratch for her son, and in saying so she ascribes her opinions to both middle-class motherhood discourses (cf. Parsons 2015: 51) and post-socialist gender order (Dunn 2004). In order to "supplement" the diet with proper home-made food she receives soups in jars prepared by the child's grandmother, finding 
herself disciplined by the idea of "home-cooked" as universally superior to "ready-made" (Dunn 2004: 196-199). "Home-made" thus refers not only to controlling the food quality, but also to controlling the people: conviction about the necessity of domestic cooking as opposed to eating out or using ready-made meals especially influences the mothers of small children. This is one reason, among others, why women of the parental generation may admit that, since their children have grown up, they could relax the discipline of daily food preparation, although the idea of cooking from scratch and sharing meals still remains valid.

Against a background of low appreciation of ready-made meals, receiving food from one's parents, amongst other meanings, may be seen as avoiding or minimising the amount of food which does not meet the assumed standards. The older generations are assumed to be closer to the "naturalness" of foodstuffs because of their memory of the (idealised) past together with the culinary competence of cooking from scratch that were shaped in conditions different from those of the present day. It is worth emphasising that, apart from single exceptions, people do not precisely reflect on the quality or taste of home-made food - it is highly valued because it is home-made. The assumption that cooking skills should improve one's diet is rather taken for granted, not only among professionals of food policy (Short 2006: 4), but also among the participants of the study. However, not only knowledge and skills but also the importance of it being handmade - understood as literally time-consuming handling of products - cannot be disregarded, especially when comparing people of different biographical experience. It is the physical contact with the consecutive stages of food production that makes a meal transparent, and as a result trustworthy (cf. Mroczkowska 2014: 81), and the parental generation is able to fulfil this obligation. Not without reason, some parents may complain either about the "laziness" of their daughters or about the heavy workloads their children have to deal with, which prevents them from spending as much time as they need to prepare a proper meal. Apparently time-to-spend is perceived as one of the key resources used in overcoming the trust deficiency, and it is not simply convertible into a financial resource.

The second resource is, evidently, specific cultural and social capital: knowledge, often embodied, combined with adequate social relations. For example the above-described meanings of home-made are complemented by a particular, self-perceived competence in the area of household provision, a competence not available to everyone. Food preparation starts not in the kitchen, but in the shop or marketplace (cf. Kopczyńska 2015: 186-187). Staying within the boundaries set by the mainstream food distribution system complemented by active negotiating of its potential seems to be more typical than searching for solutions beyond it (like alternative food networks, organic farms, etc.). Almost everybody in the research sample tries to find an individual golden mean between the imagined pureness of the food and the options available at the market. For example, there are those interviewees for whom the price of the products serves as a measure of its relative safety: the quality and the "authenticity" of the food is ensured if the cheapest products are rejected. The participants of the study may also depend on so-called "reading the label" - they declare that they study commercial information on the products, trying to avoid ingredients considered as "unnatural" or harmful. This requires knowledge from the expert systems to be incorporated into the structure of everyday life, becoming a visible manifestation of late modern reflexivity. Nevertheless, informal or embodied knowledge, rooted in the past, does not cease to play an important role. 
Some of the parental generation interviewees, especially those who stress their role in feeding the extended family, have underlined working out their own systems for purchasing foodstuffs. They admit they have created their own regular shopping routines arranged in a fixed pattern and based on linking particular foodstuffs with retailers. According to an account of a woman in her late fifties who visits her daughter almost every day to help with the grandchildren, some of the products can be bought without harm in the popular discount supermarkets, while others are strictly assigned to the small local stores. In such cases, daily shopping needs embodied, meticulous reproduction of well-known paths on foot and by car.

A much more elaborate example of a similar system was given by another participant in the study: a woman in her fifties, a caring mother as well as grandmother. She describes in detail how she and her husband purchase food every week, focusing on her personal, long-term relationships with the sellers - farmers working at local urban marketplaces. The fact she is used to preparing meals not only for herself and her husband, but also for her adult children and an elderly mother is not without significance. Her caregiver role demands particular attention given to the quality of products:

I can say that my husband and I are addicted to the farmers market. We are addicted. Of course, this is what I call it with a certain amount of humour. But we do most of the shopping at the market. [...] We buy meat there, we buy veggies, dairy products, we buy chickens there [...] and we attach great importance to the quality. This is our opinion, yes? For example we go to the farmers market where we have our lady, Bronia, from whom we buy eggs, because I know for sure that she offers free-range eggs. And I buy a hen for broth from her too. I may telephone her and say: "Miss Bronia, I need a hen for Saturday", or, for example: "I need some sour cream".

This interviewee, in a similar way, describes her relationship not only with one farmer, but also with suppliers of other foodstuffs. She clearly links certain products (beetroots, apples, nuts) with particular farmers coming to her city from the nearby villages. It is evident that she does not refer to the institutional systems of maintaining food safety (like certifications); instead she personalizes the foodstuffs, straight away referring to personal trust as a guarantor of their quality. The woman admits: "I trust that Bronia, who brings just small amounts of products to the market and she doles them out, because she needs to bring twenty for somebody, ten for somebody else or something like that. So I believe her".

The markets to which the woman refers, located in various city districts, have existed for years and are now losing their popularity in Poland (Bilewicz and Śpiewak 2015: 150). Arranged in an old-fashioned style, they differ from the new, recently emerged spaces of organic food trade which openly label themselves as an alternative to the mainstream distribution system. Since farmers sell their products in different marketplaces, changing these depending on the day of the week, the interviewee knows their schedule and tunes in to the rhythm and the geography of their work. The system seems to be elaborate both in social and geographical terms. The intention of purchasing products from particular people and in particular places implies the complexity of the shopping pattern, with the quality of the food as a priority:

Does it take a lot of time to buy provisions for the home? No, because you already know where to go, so you do not go wrong, right? Because you know, for example, that you buy vegetables 
Hidden resources? Households' strategies for maintaining control over food...

from the sisters, let's say, in Przymorze market. You know that they [vegetables] are not going to be stringy, yes, they are going to be fresh. We also have a man who sells apples.

Not all the participants in the study use such a detailed and expanded system of food supply as the one described above. Without doubt, however, one may notice an appeal to one's own resources (time, work, physical engagement, skills rooted in life experience reaching back to the previous economic system) by representatives of the older generations, as in the case of this 72-year-old woman:

Today this is... I do not know, I think it is laziness. [I think] that the older generation [...], we were not lazy. I always went to the farmers market, I shopped at the market. One knows at the market that what the old lady was selling, it was certainly a carrot without spraying [with no chemical additives]. It could be distinguished.

Effort-demanding and time-consuming patterns of purchasing food, together with working with one's own hands and sharing its results as in traditional households, are perceived as helping to manifest care and to control the quality of food. The parental generation especially perceives that as a contribution to family well-being in the times of systemic pressures. Solutions woven into everyday life were worked out in previous times and became imprinted both in the body and space. At the same time new urban ideas of food procurement are accompanied by doubts. The chosen elements of alternative food production and distribution networks (like organic farms, the new farmers' markets or the systems of certifications) are mentioned in the interviews, although they are more often perceived as a suspicious fad or marketing trick. The interviewees prefer to appeal to their own competences of evaluating food sources, based on common sense, rationality and memory, embodied knowledge, physical work and building stable relationships with the food suppliers in local shops and at traditional farmers' markets. The search for social embeddedness of the food is left to the families rather than the external entities designated for this purpose (cf. Jehlička and Smith 2011).

\section{PAST, PRESENT AND THE HIDDEN RESOURCES}

Some of my interlocutors perceive the modern food industry as evolving in the wrong direction, because it is harmful and drifting away from the idea of "real" or "pure" food. People speak about the contemporary "chemical" additives which allegedly did not exist in the earlier stages of their lives. Some of the older interviewees, similarly to the participants in the research conducted in the rural area of Eastern Poland (Mroczkowska 2014: 77), believe that contemporary life expectancy is shortened in comparison to the older generations because of the transformation of food production. Interestingly, the interviewees usually do not refer to the fact that food available in their childhood was not necessarily "traditional" or "natural". The food production in the period of socialism was influenced by rapid industrialisation taking place under the conditions of a centrally controlled, and thus periodically inefficient, economy. Nostalgic attitudes towards the past hide both the quality of the mass-produced food under socialism and the then fascination with industrial food production (Brzostek 2010: 75, 206). 
In fact the difference between "now" and "then" is more a matter of late modern knowledge production than food production. As one of the participants in the study, a woman in her sixties, notices: "Back then there was no situation that, for example, there were ordinary eggs and another kind of better eggs. There were just eggs, which were good - and that is it". Another interviewee, a 55-year-old woman, points out: "caring about what the ingredients are $[. .$.$] this, in turn, was not necessarily my mum, but my daughter, who taught me so [...]$ to be very, very attentive". The above described ways of maintaining control over food like recreating the meanings of home-made and handmade together with attempts to avoid large-scale trade - represent attitudes towards food that could be perceived as emblematic of current late modern reflexivity. Some of the solutions that participants of the study apply in their households could thus be perceived as a carbon copy of the tendencies coming from Western European societies. Not surprisingly some notions connected to "home-made" are distinctive (Bilewicz and Śpiewak 2015: 148; cf. Paddock 2015), while the younger representatives of the middle-class may be paradoxically perceived as those who are closer - in a metaphorical sense - to that imagined past.

This, however, would be just a partial interpretation. As shown above, in the Polish context representatives of the parental generation are those who have access to particular forms of protection against systemic insecurity. Their bottom-up activities at home, which some interpreted as a specific form of "civic" engagement in the socialist past (Dunn 2004), may serve as a model for today's ways of acting. The past is a resource not only in terms of evoking emotions, but also as an actual toolbox: a reservoir of skills and knowledge which could have been devaluated but are now returning to life. The convergence of two different historical periods is clearly visible on the basis of the material gathered. The question is, if the first layer (late modern lifestyle tendencies) allows the empowering of the second one by appreciating competences that for some time have been repressed or if the connection between them is blurred, invisible in people's experience. Different modes of remembering, forgetting and recalling the past under the condition of social change create complex dynamics of uprooting and re-rooting, leaving the question still open for discussion.

Contemporary trends, for example, may be powered by skills coming from the past in a way that the two origins may become indistinguishable, such as in the example of a smokehouse built by one of the families in their garden: it is difficult to say if the idea came from the influence of modern trends or from the memories of the rural family background. There are also very clear examples of "forgetting the past": a woman in her thirties may express her satisfaction with the fact that today it is trendy to eat buckwheat and millet as a "healthy novelty", not even realizing that her ancestors could have eaten it on a daily basis.

There is also a second option: people perceive the similarity of the past and the present, using the new meanings to interpret their experience shaped in past circumstances. Although not all of the interviewees make direct connections between traditional, socialist and late modern practices, some of them intuitively feel that today their past competence may be reinterpreted as a resource. For instance, a retired teacher of peasant origins is proud of making use of the small allotment her family owns in the city. They grow some fruit and vegetables there, using it both as a source of good foodstuffs and a valued leisure activity. This interlocutor notes: "Still, home-made food stops you getting sick. Things from your 
Hidden resources? Households' strategies for maintaining control over food...

own garden... At the moment a lot of actors run this kind of life, they buy a piece of land somewhere". The woman directly links her practices, although having origins in different socio-political and economical contexts, with contemporary trends. This interviewee would probably agree with Petr Jehlička and Joe Smith (2011) who, on the example of the Czech Republic, suggest reinterpreting household food self-provisioning (including gardening and barter) in post-socialist societies. They perceive it not only as a relic of past coping strategies but as a locally sensitive repository of grassroots, socially inclusive and sustainable practices which should be actively integrated into food policy.

Notions of domestic food production tell us, however, more than just about the food itself and the resistance strategies towards the food industry. The discussion about food trust in contemporary Poland may be seen as vivid exemplification of the wider but unobvious dynamics between the axis defined by the extremes: continuity/discontinuity and imitative/ inner (cf. Stenning 2005; Smith and Jehlička 2007). Two layers, thus, overlap: one is the relatively new influence of Western culture that makes the middle-class distinct - this may be seen as imitation. The second layer is the local, inner legacy: family histories and family habits, memories and the skills of mothers and grandmothers, partly forgotten or belittled, stretched between tradition and (late) modernity. Instead of being silenced, they could be appreciated as an important reference point and a repository. The influence of what is new and external paradoxically fits the legacy of socialist times, creating complex dynamics of uprooting and re-rooting. These dynamics reveal the specific character of the Polish modernisation process, which may be understood as partial or unfinished when seen through the prism of the unilineal transition paradigm, but also interpreted as complementary to the dominant vision of social change.

\section{REFERENCES}

Alber, Jens and Ulrich Kohler. 2008. Informal food production in the Enlarged European Union, "Social Indicators Research", 89, 1: 113-127.

Bachórz, Agata, Karolina Ciechorska-Kulesza, Sławomir Czarnecki, Martyna Grabowska, Jakub Knera, Lesław Michałowski, Krzysztof Stachura, Stanisław Szultka, Cezary Obracht-Prondzyński and Piotr Zbieranek. 2014. Punkty styczne. Między kultura a praktyka (nie)uczestnictwa, Gdańsk: Instytut Kultury Miejskiej, http://repozytorium.ikm.gda.pl/ items/show/108 [10.06.2018].

Bellows, Anne C. 2004. One hundred years of allotment gardens in Poland, "Food and Foodways: Explorations in the History and Culture of Human Nourishment", 12, 4: 247-276.

Bilewicz, Aleksandra and Ruta Śpiewak. 2015. Enclaves of Activism and Taste: Consumer Cooperatives in Poland as Alternative Food Networks, "Socio.hu". Special Issue in English "The Social Meaning of Food”, 3: 147-166.

Brzostek, Błażej. 2010. PRL na widelcu, Warszawa: Wydawnictwo Baobab.

Bugge, Annechen Bahr, Almås, Reidar. 2006. Domestic Dinner. Representations and Practices of a Proper Meal Among Young Suburban Mothers, "Journal of Consumer Culture", 6, 2: 203-228. 
Derek, Marta. 2017. Multi-ethnic Food in the Mono-ethnic City: Tourism, Gastronomy and Identity in Central Warsaw, in: Derek R. Hall (ed.), Tourism and Geopolitics: Issues and Concepts from Central and Eastern Europe, Wallingford: Centre for Agriculture and Biosciences International.

Domański, Henryk, Zbigniew Karpiński, Dariusz Przybysz and Justyna Straczuk. 2015. Wzory jedzenia a struktura społeczna, Warszawa: Wydawnictwo Naukowe Scholar.

Dunn, Elizabeth. 2004. Privatizing Poland: Baby Food, Big Business, and the Remaking of Labor, Cornell University Press.

DuPuis, Melanie E. and Sean Gillon. 2009. Alternative Modes of Governance: Organic as Civic Engagement, "Agriculture and Human Values", 26, 1-2: 43-56.

Claude, Fischler. 1988. Food, Self and Identity, "Social Science Information”, 27, 2: 275-292.

Goody, Jack. 2013. Industrial Food: Towards the Development of a World Cuisine, in: Carolle Counihan and Penny van Esterik (ed.), Food and Culture. A reader, Routhledge.

Horolets, Anna. 2013. Konformizm, bunt, nostalgia. Turystyka niszowa z Polski do krajów byłego ZSRR, Kraków: TAiWPN Universitas.

Jehlička, Petr and Joe Smith. 2011. An unsustainable state: Contrasting food practices and state policies in the Czech Republic,"Geoforum", 42, 3: 362-372.

Kjærnes, Unni, Mark Harvey and Alan Warde. 2007. Trust in food: A comparative and institutional analysis, Springer.

Kochanowski, Jerzy. 2015. Tylnymi drzwiami. "Czarny rynek” w Polsce 1944-1989, Warszawa: WAB.

Kopczyńska, Ewa. 2015. Co to jest jedzenie naturalne? Socjonatura na targowisku, "Studia Socjologiczne", 4, 219: 181-203.

Kopczyńska, Ewa and Katarzyna Zielińska. 2015. Feeding the Body, Feeding the Gender, "East European Politics and Societies", 30, 1: 147-168.

Mazurek, Małgorzata. 2010. Społeczeństwo kolejki. O doświadczeniach niedoboru 19451989, Warszawa: Trio.

Moiso, Risto, Eric J. Arnould and Linda L. Price. 2004. Between Mothers and Markets Constructing family identity through homemade food, "Journal of Consumer Culture" 4, 3: 361-384.

Mroczkowska, Joanna. 2014. Gospodyni, matka, uzdrowicielka. Rola kuchni w kształtowaniu tożsamości współczesnych kobiet wiejskich, in: Urszula Jarecka and Anna Wieczorkiewicz (ed.), Terytoria smaku. Studia z antropologii i socjologii jedzenia, Warszawa: Wydawnictwo IFiS PAN.

Murcott, Anne. 1982. On the Significance of the Cooked Dinner in South Wales, "Social Science Information", 21: 677-696.

Paddock, Jessica. 2015. Positioning Food Cultures: 'Alternative’ Food as Distinctive Consumer Practice, "Sociology”, 50, 6: 1039-1055.

Palska, Hanna. 2002. Bieda i dostatek. O nowych stylach życia w Polsce końca lat dziewięćdziesiatych, Warszawa: Wydawnictwo IFiS PAN.

Parsons, Julie M. 2015. Gender, Class and Food Families, Bodies and Health, Palgrave Macmillan.

Rakowski, Tomasz. 2009. Łowcy, zbieracze, praktycy niemocy. Etnografia człowieka zdegradowanego, Gdańsk: Słowo/ Obraz Terytoria. 
Hidden resources? Households' strategies for maintaining control over food...

Ries, Nancy. 2009. Potato ontology: Surviving Postsocialism in Russia, "Cultural Anthropology", 24, 2: 181-212.

Short, Frances. 2006. Kitchen Secrets: The Meaning of Cooking in Everyday Life, Oxford: Berg.

Smith, Joe and Petr Jehlička. 2007. Stories around food, politics and change in Poland and the Czech Republic, "Transactions of the Institute of British Geographers", 32: 395-410.

Smith, Adrian and Alison Stenning. 2006. Beyond household economies: articulations and spaces of economic practice in postsocialism, "Progress in Human Geography", 30, 2: 190-213.

Stenning, Alison. 2005. Post-socialism and changing geographies of the everyday in Poland, "Transactions of the Institute of British Geographers", 30: 113-127.

Warde, Alan and Lydia Martens. 2003. Eating Out: Social Differentiation, Consumption and Pleasure, Cambridge University Press.

Wedel, Janine R. 2007. Prywatna Polska, Warszawa: Trio.

\section{UKRYTE ZASOBY? STRATEGIE UTRZYMANIA KONTROLI NAD ŻYWNOŚCIĄ W GOSPODARSTWACH DOMOWYCH: MIĘDZY CIĄGŁOŚCIĄ A ZMIANĄ}

W niniejszym artykule omówione zostały stosowane w Polsce wewnętrzne strategie gospodarstw domowych dotyczące odzyskiwania kontroli nad jakością, bezpieczeństwem i znaczeniem żywności. Korzystając z materiałów zebranych podczas wywiadów z przedstawicielami dwóch pokoleń, przeanalizowano oddolne, rozproszone i wewnątrzrodzinne rozwiązania, stanowiące część ich życia codziennego. Chociaż współcześnie to alternatywne sieci żywnościowe i aktywizm żywnościowy są uważane za ważne narzędzia krytyki mechanizmów przemysłowej produkcji i dystrybucji jedzenia, artykuł odnosi się do codziennych wyborów dokonywanych z ich pominięciem jako bardziej charakterystycznych dla społeczeństwa polskiego. Domowe sposoby przyrządzania posiłków i zaopatrywania gospodarstwa domowego - jako ucieleśnione umiejętności oparte na pracy fizycznej i czasie, który ma się do dyspozycji - zostały w artykule zinterpretowane w świetle współczesnej nieufności wobec żywności. Zgromadzony materiał empiryczny dotyczy przede wszystkim przedstawicieli klas średnich, co do których można by oczekiwać, że chętniej niż inni przyjmą elementy nowych stylów życia, w tym także w sferze żywienia. Okazuje się jednak, że również w ich przypadku warto skupić się nie tylko na zmianach, ale przede wszystkim - na ciągłości. Nacisk został położony na podobieństwo między późnonowoczesnymi i tradycyjnymi mechanizmami utrzymywania zaufania do żywności, co wskazuje na nakładanie się na siebie różnych warstw historycznych i specyfikę polskich procesów modernizacyjnych.

Słowa kluczowe: zaufanie do żywności, żywność domowa, ekonomia gospodarstwa domowego, przekaz międzypokoleniowy, tradycja, nowoczesność, postsocjalizm 